\title{
Pond Niche Based Integrated Farming: A Case Study in Tripura, India
}

\author{
Nongthombam Dorendo Singh, Atanu Sarkar*, Pradyut Biswas, Prasanjit Pal and Anil Datt Upadhyay
}

College of Fisheries, Central Agricultural University (Imphal), Lembucherra, Tripura (799 210), India

\section{Corresponding Author}

Atanu Sarkar

e-mail: atanusarkar1954@gmail.com

\author{
Article History \\ Article ID: AR1860 \\ Received in $29^{\text {th }}$ January, 2018 \\ Received in revised form $26^{\text {th }}$ April, 2018 \\ Accepted in final form $28^{\text {th }}$ May, 2018
}

\begin{abstract}
The article is based on a study conducted during December, 2016 to February, 2017 in West Tripura district of Tripura (India) to examine the status of pond niche based integrated farming and identify perceived constraints associated with systematic practicing of the same. Findings suggested that despite pursuing of integrated farming in varied forms with practice of fish culture alongside different combinations of other enterprises, the average fish productivity for in-practice respondents was only $515.89 \mathrm{~kg} \mathrm{ha}^{-1}$, which was lagging behind by 4.70 times than the state average $\left(2429.20 \mathrm{~kg} \mathrm{ha}^{-1}\right)$ and around 5.13 times than the average of district under study $\left(2650.40 \mathrm{~kg} \mathrm{ha}^{-1}\right)$. Further, the average annual income flow by combining all pond niche based enterprises was also insufficient (₹ 19641/- per surveyed household). This suggested only limited success of the fish based integrated farming in the study area. The most important constraints perceived as deterring systematic practicing of integrated farming were: 'no clear idea on how to effectively integrate crop, livestock etc. around the pond'; 'dearth of required technical guidance from a single institutional source in a synchronized manner'; 'lack of extension activity to locally demonstrate worthiness of integrated farming and/or exposure visit to successful sites to show how things have happened'; 'business/service/agriculture/wage earning being main occupation, can't concentrate seriously on integration'; and 'inadequate training support on the subject'. Therefore, much more systematic institutional interventions are required for due ideation, motive building and skill empowerment on the domain of aquatic niche based integrated farming.
\end{abstract}

Keywords: Integrated farming, pond niches, income flow, constraints

\section{Introduction}

Integrated Farming represents an appropriate mix of farm enterprises like horticulture, livestock, fishery, forestry, poultry etc. and the means available to the farmer to raise them for profitability (Jayanthi et al., 2002). It is a decision making unit towards whole farm management system in order to deliver more sustainable agriculture to transform land, capital and labour into useful products, which can be consumed or sold (Fresco and Westphal, 1988). Integrated Farming involving aquaculture has been broadly defined as the concurrent or sequential linkage between two or more activities, of which at least one would be aquaculture. Here, benefits of integration are synergistic rather than additive; and the fish, livestock, agriculture or other suitable components may benefit to varying degrees (Taiganides, 1978). In India, this kind of farming derives inputs chiefly from agriculture and animal husbandry that consists of the culture of fish combined with the husbandry of domesticated animals such as pigs, ducks, poultry, cattle, etc. as well as small horticulture on the dykes or over scaffolds around the ponds.

Tripura is an economically backward state in the north-east region of India. Here, the economy is primarily agrarian in nature and agriculture has been contributing about $64 \%$ of total employment as well as about $23 \%$ of the State Domestic Product (Anonymous, 2015). It is demographically featured by the substantially high presence of weaker communities $(31.8 \%$ Scheduled Tribes, 17.8\% Scheduled Castes and 24.48\% Other Backward Castes). Only $24 \%$ of 10,492 sq. km. geographical area in the state is under cultivation due to existence of substantial presence of forest area (60\% forested area of which $39 \%$ is under reserve forest) and un-cultivable hilly terrains. The state has also been experiencing shrinkage in average size of holding, which had come down to only 0.49 ha in 2010-11 as compared to 1.25 ha in 1976-77 (Anonymous, 2014a). In the face of such shrinking average size of holding, balanced growth in the state necessitates more equitable and efficient utilization of its land resources. And towards that direction, the state has been in the process of aggressive execution of the Rain Fed Area Development Programme (RADP) wherein, based upon potentials of different farming systems, holistic agriculture development through Integrated Farming System (IFS) comprises a vital component to enhance the food and livelihood security especially of the small and 
marginal farmers through maximization of their farm returns.

Keeping this in view and in due consideration of the strength of Tripura in having the endowment of 148010 numbers of ponds/tanks to cover an area of 16016.81 ha (Anonymous, 2014b), a case study was conducted especially to gain insight on the status of pond based integrated farming in Tripura and identify the perceived constraints associated with systematic practicing of fish based integrated farming by the pond owning community under study.

\section{Materials and Methods}

\subsection{Study sites}

The study was conducted during December, 2016 to February, 2017 by resorting to ex post facto research design at two out of three sub-divisions of West Tripura district of Tripura state (India) and those sub-divisions were Mohanpur and Jirania. For the primary survey, two blocks from each of those selected sub-divisions were randomly pooled and the so selected blocks were Mohanpur and Hezamara for Mohanpur sub-division and Jirania as well as Mandai from Jirania sub-division. At the next stage, two villages were randomly selected from each of the aforesaid four blocks after their short listing on the criteria that farm pond based fishery did form an important livelihood activity therein. Thus, altogether eight villages got selection. Finally, 60 numbers of pond owning aquaculturists were pooled from those villages through probability proportionate to size sampling from eight separate lists prepared for each of the identified village in consultation with the local panchayat functionaries and village key informants as to who were in practice of fish farming along with other field crops, livestock, plantation, etc. in the pond surroundings.

\subsection{Data collection and analysis}

Data was collected by employing pre-tested structured interview schedule. In order to understand the modality of integration and associated performance under different pond based situations, five parameters were taken into consideration viz. pattern of in-practice enterprise combinations under pond niche based farming situations; productive performance of pond based fish enterprise vis-a-vis income flow from it; income flow from pond surroundings based miscellaneous enterprises; overall income pattern from all enterprise sources; and training exposure. For computing average annual fish productivity, firstly culture period vis-a-vis study period wise combined production performances of fish for each respondent was determined and then the mean value at aggregate level for the entire study period was calculated to finally estimate the annual values in $\mathrm{kg} \mathrm{ha}^{-1}$. The income flow from the ponds and surroundings was worked out in terms of average annual /monthly income accrued through both culture fisheries as well as pond dyke and trellis based small horticulture and/or raising plantation crops. Side by side, their distributive pattern across various income range categories was also worked out.
The perceived constraints of integration were firstly identified by utilizing preferential ranking technique. Then, rank based quotient (RBQ) of each of the preferentially ranked constraints was determined in conformity with the following procedure as suggested by Sabarathnam (1988):

$R B Q=\frac{f i\left(n+1-i^{\text {th }} \text { value }\right)}{N \times n} \times 100$

Where, fi=Number of respondents reporting a particular problem under $\mathrm{i}^{\text {th }}$ rank.

$\mathrm{N}=$ Total number of respondents

$\mathrm{n}=$ Number of identified problems

\section{Results and Discussion}

\subsection{Pattern of in-practice enterprise combinations under pond based farming situations}

In the larger context of shrinkage of average size of holding in a continuous manner in Tripura since around mid '70s, the issue of efficient management of that shrinking land base through integrated farming became important especially for the resource poor farm families of the state. And such necessity had equal significance for the large majority of the families in the area under investigation too due to the fact that the average size of holding for the surveyed household $(0.35$ ha) was even less than the state average of 0.49 ha (Table 1 ).

Table 1: Distribution of sample respondents according to size of land holding $(n=60)$

\begin{tabular}{lccc}
\hline $\begin{array}{l}\text { Land holding size } \\
\text { (ha.) }\end{array}$ & Frequency & Percentage & $\begin{array}{c}\text { Average size } \\
\text { of land hold- } \\
\text { ing (ha.) }\end{array}$ \\
\hline Small $(<0.22)$ & 02 & 3.33 & \\
Medium (0.22 to & 56 & 93.33 & 0.35 \\
$0.48)$ & & & \\
Large $(>0.48)$ & 02 & 3.33 & \\
\hline
\end{tabular}

Thus, being interested to gain knowledge as to how those sections of land poor farming gentry had been adjusting their land based occupational strategy in look for an improved livelihood and in the face of owning of ponds by all those surveyed respondents, it was endeavored to analyze the pattern of integration in vogue across the area with focus on different pond based farming situations of those respondents. And from that count, it got transpired from the Table 2 that keeping their ponds at the center stage, each of the sample respondents were pursuing so called integrated farming in varied forms to practice fish culture along with different combinations of other enterprises around their respective aquatic niches. As per the ranking of various combinations of enterprises put under practice by them, while $31.67 \%$ of the respondents with the practice of composite fish culture [Indian Major Carp (IMC)+Common Carp $(C C)+$ Grass Carp (GC)]+vegetables+plantation 
(banana/areca nut) appeared to assume the highest rank, the other combinations identified in descending order were composite fish culture $(\mathrm{IMC}+\mathrm{CC}+\mathrm{GC})+$ plantation (Rank-II, 28.33\% respondents), composite fish culture (IMC+CC+GC)+vegetables (Rank-III,11.67\% respondents), composite fish culture $(\mathrm{IMC}+\mathrm{CC}+\mathrm{GC})+$ plantation+duckery (Rank-IV, $10.00 \%$ respondents), and composite fish culture $(\mathrm{IMC}+\mathrm{CC}+\mathrm{GC})+$ vegetables+dairy (Rank-V, $5.00 \%$ respondents). These apart, whereas the combinations like composite fish culture (IMC+CC+GC)+vegetables+chicken, composite fish culture $(\mathrm{IMC}+\mathrm{CC}+\mathrm{GC})+$ vegetables+plantatio $\mathrm{n}+$ chicken and composite fish culture $(\mathrm{IMC}+\mathrm{CC}+\mathrm{GC})+$ veget ables+plantation+duckery had jointly assumed the Rank-VI (3.33\% respondents), the other combinations in the forms of composite fish culture (IMC+CC+GC)+plantation+chicken, and composite fish culture (IMC+CC+GC)+vegetables+plan tation+duckery did find preference from only $1.67 \%$ of the respondents (Rank-VII).

3.2. productive performance of pond based fish enterprise vis-a-vis income flow from it

It might look nice from the reflection arising out of the Table 2 that in perfect conformity with the basic tenet of integrated farming, which relies on sustainable whole farm management system with due synergistic integration of the components like fish, livestock, agri-horticultural or plantation crops in various combinations, the sample respondents had also been carrying forward integrated farming keeping their fish ponds at the center stage. But, in reality, the scenario was far from encouraging as got transpired from a glance at the table 3 , which gave an altogether deplorable picture of the outcome of such apparently encouraging practice of integrated farming as had emerged from the Table 2.

A score of studies conducted on the benefits of integrated farming by Sharma et al. (1991), Rangaswamy et al. (1996), Bosma et al. (2005), Tipraqsa et al. (2007), Biswas (2010), Nagaraju et al. (2017), etc., were un-dubiously being indicative of the much higher capability of such practice over conventional farming to enhance farm productivity and income efficiency especially for small production systems, apart from its other prospective cutting edge benefits like allowing better use of farm resources, saving of capital, creating scope for gainful employment of the family members round the year, and so on. But, for the present research investigation, the empirical evidence spoke differently in the sense that the four years' average fish productivity between 2012-13 to 2015-16 of the in-practice respondents of integrated farming appeared to be only $515.89 \mathrm{~kg} \mathrm{ha}^{-1}$, which was lagging behind by a staggering 4.70 times than that of the state average ( $\left.2429.20 \mathrm{~kg} \mathrm{ha}^{-1}\right)$ and even less by 5.13 times from that of the district of West Tripura (2650.40 kg ha-1), where the present study was carried out (Table 3).

In congruence with the very poor productive performance of the core component of integrated system (i.e. fish culture),
Table 2: Pattern of integration under different pond based farming system $(n=60)$

\begin{tabular}{|c|c|c|c|c|}
\hline $\begin{array}{l}\text { SI. } \\
\text { No. }\end{array}$ & Components & $\begin{array}{l}\text { No. of } \\
\text { respon- } \\
\text { dent }\end{array}$ & $\begin{array}{l}\text { Per- } \\
\text { cent- } \\
\text { age (\%) }\end{array}$ & Rank \\
\hline 1. & $\begin{array}{l}\text { Composite fish culture } \\
(\mathrm{IMC}+\mathrm{CC}+\mathrm{GC})+\text { vegetables }\end{array}$ & 7 & 11.67 & III \\
\hline 2. & $\begin{array}{l}\text { Composite fish culture } \\
(\mathrm{IMC}+\mathrm{CC}+\mathrm{GC})+\text { plantation }\end{array}$ & 17 & 28.33 & II \\
\hline 3. & $\begin{array}{l}\text { Composite fish culture (I } \\
M C+C C+G C)+ \text { vegetables+ } \\
\text { plantation }\end{array}$ & 19 & 31.67 & I \\
\hline 4. & $\begin{array}{l}\text { Composite fish culture } \\
(\mathrm{IMC}+\mathrm{CC}+\mathrm{GC})+\text { vegetables } \\
\text { +poultry }\end{array}$ & 2 & 3.33 & VI \\
\hline 5. & $\begin{array}{l}\text { Composite fish culture } \\
(I M C+C C+G C)+\text { plantation } \\
\text { +poultry }\end{array}$ & 1 & 1.67 & VII \\
\hline 6. & $\begin{array}{l}\text { Composite fish culture } \\
(\mathrm{IMC}+\mathrm{CC}+\mathrm{GC})+\text { plantation } \\
+ \text { ducker }\end{array}$ & 6 & 10.00 & IV \\
\hline 7. & $\begin{array}{l}\text { Composite fish culture } \\
(\mathrm{IMC}+\mathrm{CC}+\mathrm{GC})+\text { Vegetables } \\
\text { +dairy }\end{array}$ & 3 & 5.00 & V \\
\hline 8. & $\begin{array}{l}\text { Composite fish culture } \\
(I M C+C C+G C)+\text { Vegeta- } \\
\text { bles+ plantation+poultry }\end{array}$ & 2 & 3.33 & VI \\
\hline 9. & $\begin{array}{l}\text { Composite fish culture (IM } \\
\mathrm{C}+\mathrm{CC}+\mathrm{GC})+ \text { Vegetables+pla } \\
\text { ntation+dairy }\end{array}$ & 1 & 1.67 & VII \\
\hline 10. & $\begin{array}{l}\text { Composite fish culture (IM } \\
\mathrm{C}+\mathrm{CC}+\mathrm{GC})+ \text { Vegetables+pla } \\
\text { ntation+ducker }\end{array}$ & 2 & 3.33 & VI \\
\hline
\end{tabular}

IMC: Indian major carp; CC: Common carp; GC: Grass carp

Table 3: Comparison of fish productivity in respondents' ponds with district and state averages

Average annual fish productivity from culture fisheries $(\mathrm{kg}$ ha $\left.^{-1}\right)^{*}$

\begin{tabular}{lllcc}
\hline Tripura & West & Ponds of & \multicolumn{2}{c}{ Shortfall } \\
\cline { 4 - 5 } & Tripura & $\begin{array}{l}\text { respon }- \\
\text { dents }\end{array}$ & $\begin{array}{c}\text { From state } \\
\text { average }\end{array}$ & $\begin{array}{c}\text { From district } \\
\text { average }\end{array}$ \\
\hline 2429.20 & 2650.40 & 515.89 & 4.70 times & 5.13 times \\
\hline
\end{tabular}

(*Average annual fish productivity was worked out by combining corresponding data between 2012-13 to 2015-16)

the economic performance was also traced out to be utterly unsatisfactory. The revelation from table 4 was suggestive that the average annual income flow of the sample respondents was to the tune of ₹ $11490 /$ - from fish culture in the ponds 
to indicate even less than ₹ 960/- month $^{-1}$ from that core component of earning. Further, while $66.67 \%$ of them were observed to be in the annual income range between >₹5000 to ₹ 10000 , the next descending income order category was being occupied by the income range of up to ` 5000 (30.00\%). Only $1.67 \%$ of the respondents were found to have been occupied by each of the annual income range category of $>₹ 15000$ to $₹ 20000$, and $>₹ 20000$ to $₹ 25000$. It requires a mention here that the average size of ponds for the whole of the sample respondents was 0.14 ha excluding the surroundings meant for integration of other miscellaneous enterprises as per suitability/choice.

\subsection{Income flow from pond surroundings based miscellaneous} enterprises

Keeping parity with the poor productive vis-à-vis economic performance as had been occurring in case of pond based fish enterprise, the economic performance of the same aquatic niche based other miscellaneous enterprises like small horticulture on seasonal basis/plantation crops dominated by areca nut/banana/duckery/small dairy/chicken rearing etc., were also traced out to be grossly insufficient. The average annual income flow to the households of the respondents from that segment of so called integrated farming was found to be ₹ 8151/- to indicate even less than ₹ 680/- per month (Table 5).

It might further be observed from table 5 that in terms of income flow from pond surroundings based miscellaneous enterprises, while $38.33 \%$ of the respondents were in the income range category between $>₹ 5000$ to $₹ 10000$, in descending order the other categories were being occupied by the income range of up to ₹ 5000 (36.33\%), >₹ 10000 to ₹ 15000 (11.67\%), >₹ 20000 to ₹ 25000 (8.33\%), >₹ 15000 to ₹ 20000 (3.33\%), and >₹ 25000 to ₹ 30000 (1.67\%).

\subsection{Overall income pattern from all enterprise sources}

Taking cues from Tables 4 and 5, a further effort was made for portraying the overall state of affairs with respect to the pattern of annual income flow by combining all pond niche

Table 4: Pattern of income flow from pond based fish enterprise $(n=60)$

\begin{tabular}{lcccc}
\hline $\begin{array}{l}\text { Annual income } \\
\text { range from pond } \\
\text { based fish enter- }\end{array}$ & $\begin{array}{c}\text { Fre- } \\
\text { quency }\end{array}$ & $\begin{array}{c}\text { Percent- } \\
\text { age }\end{array}$ & & $\begin{array}{c}\text { Average income } \\
\text { flow (₹) }\end{array}$ \\
\cline { 4 - 5 } & & & Annual Monthly \\
Up to 5000 & 18 & 30.00 & & \\
$>5000$ to 10000 & 40 & 66.67 & & \\
$>10000$ to 15000 & 0 & 0.00 & 11490 & 958 \\
$>15000$ to 20000 & 1 & 1.67 & & \\
$>20000$ to 25000 & 1 & 1.67 & & \\
$>25000$ to 30000 & 0 & 0.00 & \\
$>30000$ & 0 & 0.00 & \\
\hline
\end{tabular}

Table 5: Pattern of income flow from pond surroundings based miscellaneous enterprises $(n=60)$

\begin{tabular}{|c|c|c|c|c|}
\hline \multirow{2}{*}{$\begin{array}{l}\text { Annual income } \\
\text { range from pond } \\
\text { surroundings } \\
\text { based misc. } \\
\text { enterprises (₹) }\end{array}$} & \multirow[t]{2}{*}{$\begin{array}{c}\text { Fre- } \\
\text { quency }\end{array}$} & \multirow[t]{2}{*}{$\begin{array}{l}\text { Percent- } \\
\text { age }\end{array}$} & \multicolumn{2}{|c|}{$\begin{array}{c}\text { Average income } \\
\text { flow (₹) }\end{array}$} \\
\hline & & & Annual & Monthly \\
\hline Up to 5000 & 22 & 36.33 & & \\
\hline$>5000$ to 10000 & 23 & 38.33 & & \\
\hline$>10000$ to 15000 & 07 & 11.67 & 8151 & 679 \\
\hline$>15000$ to 20000 & 02 & 3.33 & & \\
\hline$>20000$ to 25000 & 05 & 8.33 & & \\
\hline$>25000$ to 30000 & 01 & 1.67 & & \\
\hline$>30000$ & 00 & 0.00 & & \\
\hline
\end{tabular}

based enterprises as had been in practice by the sample respondents while performing their ways of integrated farming. And here, it became transpired from table 6 that the average annual income being accumulated by them was ₹ $19641 /$ - to, in turn, signify average monthly distributive pattern of the same being around ₹ 1637/- per surveyed household.

It was also observed from the same Table 6 that in terms of the pattern of annual income flow by combining all pond niche based enterprises, while $38.33 \%$ of the respondents were falling in the category of income range between $>₹ 10000$ to $₹ 20000$, in descending order the other categories were being occupied by the income range categories of $>₹ 20000$ to 30000 (31.67\%), up to >₹ 10000 (15.00\%), >₹ 30000 to ₹ 40000 (10.00\%), >₹ 40000 to ₹ 50000 (3.33\%), and >₹ 50000 (1.67\%).

Table 6: Pattern of income flow from integration of all pond niche based enterprises $(n=60)$

\begin{tabular}{|c|c|c|c|c|}
\hline \multirow{2}{*}{$\begin{array}{l}\text { Annual income } \\
\text { range from inte- } \\
\text { gration of all pond } \\
\text { niche based enter- } \\
\text { prises (₹) }\end{array}$} & \multirow[t]{2}{*}{$\begin{array}{l}\text { Fre- } \\
\text { quency }\end{array}$} & \multirow[t]{2}{*}{$\begin{array}{l}\text { Percent- } \\
\text { age }\end{array}$} & \multicolumn{2}{|c|}{$\begin{array}{c}\text { Average income } \\
\text { flow (₹) }\end{array}$} \\
\hline & & & Annual & Monthly \\
\hline Up to 10000 & 9 & 15.00 & & \\
\hline$>10000$ to 20000 & 23 & 38.33 & & \\
\hline$>20000$ to 30000 & 19 & 31.67 & 19641 & 1637 \\
\hline$>30000$ to 40000 & 6 & 10.00 & & \\
\hline$>40000$ to 50000 & 2 & 3.33 & & \\
\hline$>50000$ & 1 & 1.67 & & \\
\hline$>30000$ & 0 & 0.00 & & \\
\hline
\end{tabular}

\subsection{Training exposure}

The outcome of a score of studies as conducted by Singh et al. (1993); Bhat and Das (2002); Singh (2002); Raghunandan 
(2004), Poorani et al. (2011) etc. were reflective of the necessity of training and updating of knowledge of the farmers on integrated farming in order to have better adoption of the system. The enormous lack of efficiency in the management mechanism of both the core component (i.e. culture fisheries) as well as the same aquatic niche based other miscellaneous enterprises of the so called forms of integrated farming practices by the respondents of the present study also maintained congruence with those earlier revelations to strongly justify the utter need for appropriate undertaking of motivation building exercises as well as assimilation of the technological niceties contextual to systematic integrated farming by the relevant state departments and other institutions. But, regardless of the genuine necessity of extending strategic training support on those counts, none of the training courses, which were noted to be participated by $65.00 \%$ of the surveyed population during the five years span between 2011-12 to 2015-16, dealt with the very subject matter domain of integrated farming and required motive building vis-à-vis skill inculcation associated with the same (Table 7).

Another notable revelation from Table 7 was in terms of the

Table 7: Training exposure of respondents during 2011-12 to $2015-16(n=60)$

\begin{tabular}{lcc}
\hline Training exposure & Frequency & Percentage (\%) \\
\hline $\begin{array}{l}\text { Attended training pro- } \\
\text { gramme }\end{array}$ & 39 & 65.00 \\
Area of training & & \\
\hline $\begin{array}{l}\text { - Composite fish farming } \\
\text { practices (2 days) }\end{array}$ & $\bullet 20$ & $\bullet 51.28$ \\
$\begin{array}{l}\text { Scientific fish culture } \\
\text { practices (2 days) }\end{array}$ & $\bullet 19$ & $\bullet 48.72$ \\
$\begin{array}{l}\text { Not attended any training } \\
\text { programme }\end{array}$ & 21 & 35.00 \\
\hline
\end{tabular}

duration of the courses. Even though few training courses were observed to be undergone by the respondents on composite/ scientific fish culture i.e. the core component of integration under present context, duration of all of those were for two days only, so the issue of skill development on that vocational domain too could not be effectively addressed as a natural case to denote manifestation of very poor productive as well as economic performance of that component.

\subsection{Perceived constraints of systematic practicing of fish based integrated farming}

The constraints, as perceived by the respondents to be deterring the systematic practicing of fish based integrated farming were prioritized through employment of preferential ranking technique. The outcome of such exercise, as got presented through Table 8, indicated 'no clear idea on how to effectively integrate crop, livestock etc. around the pond'
Table 8: Ranking of perceived constraints of the respondents on integrated farming $(n=60)$

\begin{tabular}{lcc}
\hline SI. Nature of constraint & RBQ & Rank \\
No. & value & \\
\hline
\end{tabular}

Socio-personal Constraints

1. Business/service/agriculture/wage earning being main occupation, can't concentrate seriously on integration

2. Pond location is away from home, so 23.07 VIII difficult to supervise regularly

Economic Constraints

3. Higher cost involvement $\quad 16.67 \quad \mathrm{IX}$

4. Lack of financial assistance for higher $27.82 \quad$ VII initial investment

Technological Constraints

5. No clear idea on how to effectively 91.67 । integrate crop, livestock etc. around the pond

6. Dearth of technical guidance from a single institutional source in a synchronized manner

7. Lack of timely availability of inputs required for integration of suggested components

Promotional Constraints

8. Lack of information support and $32.82 \quad$ VI guidance on government schemes to support such combined activities

9. Lack of extension activity to locally 55.00 III demonstrate worthiness of integrated farming and/or exposure visit to successful sites to show how things have happened

10. Inadequate training support on the $38.07 \quad \mathrm{~V}$ subject

to be the prime constraint ( $\mathrm{RBQ}$ value 91.67). In descending order, the other nine perceived constraints noted to be: 'dearth of technical guidance from a single institutional source in a synchronized manner' (RBQ value 76.92); 'lack of extension activity to locally demonstrate worthiness of integrated farming and/or exposure visit to successful sites to show how things have happened' (RBQ value 55.00); 'business/service/agriculture/wage earning being main occupation, can't concentrate seriously on integration' (RBQ value 47.43); 'inadequate training support on the subject' (RBQ value 38.07); 'lack of information support and guidance on government schemes to support such combined activities' 
(RBQ value 32.82); 'lack of financial assistance for higher initial investment' (RBQ value 27.82); 'pond location is away from home, so difficult to supervise regularly' (RBQ value 23.07); 'higher cost involvement' (RBQ value 16.67); and 'lack of timely availability of inputs required for integration of suggested components' (RBQ value 12.82).

\section{Conclusion}

The pond niche based integrated farming found its limited success in the study area. Institutional interventions need to play on ideation, motive building and skill empowerment of the clients through rendering training support, organizing in situ demonstrations and arranging exposure visits to build concept and confidence. Further, Krishi Vigyan Kendras (KVKs), State Skill Development Directorate may provide technical guidance to bridge the knowledge gap.

\section{References}

Anonymous, 2014a. Agriculture Census 2010-11: All India report on number and area of operational holdings, agriculture census division, Department of Agriculture \& Co-Operation Ministry of Agriculture, Government of India.

Anonymous, 2014b. Fisheries Statistics 2013-14. Department of Fisheries, Govt. of Tripura. Web. http://www. tripurafisheries.nic.in. Accessed March 24, 2016.

Anonymous, 2015. Report of the Joint Inspection Team on its visit to Tripura to review the progress under the Mission for Integrated Development of Horticulture (MIDH), Ministry of Agriculture, Department of Agriculture \& Cooperation, Krishi Bhawan, New Delhi. Web.http:// nhm.nic.in/JIT_Reports/05092015.pdf. Accessed May 24, 2017.

Bhat, P.N., Das, N., 2002. Report of the working group on Animal Husbandry and dairying for the Tenth Plan 200207. Food and nutrition security. Govt. of India, Planning Commission, New Delhi, 318.

Biswas, B.C., 2010. Farming system approach to improve IUE, employment and income in Eastern India. Fertiliser Marketing News 41(5), 6-12.

Bosma, R.H., Udo, H.M.J., Verreth, J.A.J., Visser, L.E., Nam, C.Q., 2005. Agriculture diversification in the Mekong Delta: farmers' motives and contributions to livelihoods. Asian Journal of Agriculture and Development 2 (1\&2), 49-66.

Fresco, L.O., Westphal, E., 1988. A hierarchical classification of farm systems. Experimental Agriculture 24(4), 399-419.
Jayanthi, C., Malarvizhi, P., Fazullah Khan, A.K., Chinnusamy, C., 2002. Integrated nutrient management in forage oat (Avena sativa). Indian Journal of Agronomy 47(1), 130-133.

Nagaraju, Y., Raghavendra, N., Basavaraj, B., 2017. Livelihood enhancement of vulnerable farm families through integrated farming systems of southern districts of Karnataka. International Journal of Science and Research 6(1), 389-393.

Poorani, A., Jayanthi, C., Vennila, C., 2011. Farmer participatory research on integrated farming systems. In: National seminar on innovations in farming systems research and extension for inclusive development, 24 -25 Nov, 2011, Madras Veterinary College, Chennai, 153.

Raghunandan, H.C., 2004. A study on knowledge and adoption level of soil and water conservation practices by farmers in northern Karnataka: M.Sc. (Agriculture) Thesis, University of Agricultural Sciences, Dharwad, Karnataka, India.

Rangasamy, A., Venkatswamy, R., Premshekhar, M., Jayanthi, C., Palaniappan, S.P., 1996. Integrated farming systems for rice based ecosystem. Madras Agricultural Journal 82(4), 290-293.

Sabarathnam, V.E., 1988. Manual on field experience training for ARS Scientists. National Academy of Agricultural Research Management, Rajendranagar, Hyderabad 50030, India.

Sharma, L.R., Bhati, J.P., Singh, R., 1991. Emerging farming systems in Himachal Pradesh: Key issues in sustainability. Indian Journal of Agricultural Economics, 46(3), 421-427.

Singh, K. P., 2002. Integrated farming systems for small holders - A key issue for research-education-extension linkages in semi-arid tropical conditions. Paper presented to $17^{\text {th }}$ Symposium of the International Farming Association, 17-20 Nov., 2002. Orlando, Florida, USA.

Singh, K.P., Singh, S.N., Kumar, H., Kadian, V.S., Saxena, K.K., 1993. Economic analysis of different farming systems followed on small and marginal land holdings in Haryana. Haryana Journal of Agronomy 9, 122-125.

Taiganides, E.P., 1978. Principles and techniques of animal waste management and utilization. FAO Soils Bull Bulletin, 36, 341-362.

Tipraqsa, P., Craswell., E.T., Noble, A.D., Schmidt, V.D., 2007. Resource integration for multiple benefits: multifunctionality of integrated farming systems in Northeast Thailand. Agricultural Systems 94, 694-703. 